\title{
PENETAPAN KAWASAN ANDALAN SEBAGAI PUSAT PERTUMBUHAN PADA TINGKAT KABUPATEN/KOTA DI KALIMANTAN TIMUR
}

\author{
Oleh: \\ Dwi Dhasta Wahyuningtiyas \\ Staff PT. Jhon Crane Indonesia \\ E-mail/No. Hp: dhastablue@yahoo.com/-
}

\begin{abstract}
The objective of this study was to identify how the patterns of economic growth was, to know what sector which was able to develop in an effort to determine development priorities, and analyze where the leading region as a center of economic growth on Regency/ city level in in East Kalimantan. While the supreme sector at regency/ city in East Kalimantan, based on the calculation of Location quotient $(L Q)$ are supreme agricultural sector in the regency of Malinau, superior mining \& quarrying sector in East Kutai regency, superior processing industry sector in Bontang City, the superior electricity sector, gas \& water supply in the city of Tarakan, superior construction sector in the city of Balikpapan, trade, hotels \& restaurants sector in the City of Tarakan, supreme transport \& communications sector in Samarinda, the supreme financial, rental \& services company sector in Samarinda City, and superior services sector in Samarinda. The leading areas as growth center on regency/ city level in East Kalimantan were Balikpapan and Tarakan City.
\end{abstract}

Keywords: Typology klassen, location quotient (LQ), leading regions.

\begin{abstract}
Abstrak
Tujuan dari penelitian ini adalah mengidentifikasi bagaimana pola pertumbuhan ekonomi, mengetahui sektor apa saja yang bisa dikembangkan dalam upaya menentukan prioritas pembangunan, serta menganalisa dimana kawasan andalan sebagai pusat pertumbuhan ekonomi pada tingkat kabupaten/kota di Kalimantan timur.Sedangkan Sektor yang menjadi unggulan pada tingkat Kabupaten/Kota di Kalimantan Timur berdasarkan perhitungan Location Quotient (LQ) adalah sektor pertanian unggul di Kabupaten Malinau, sektor pertambangan \& penggalian unggul di Kabupaten Kutai Timur, sektor industri pengolahan unggul di Kota Bontang, sektor listrik, gas \& air bersih unggul di Kota Tarakan, sektor konstruksi unggul di Kota Balikpapan, sektor perdagangan, hotel \& restoran unggul di Kota Tarakan, sektor pengangkutan \& komunikasi unggul di Kota Samarinda, sektor keuangan, persewaan \& jasa perusahaan unggul di Kota Samarinda, dan sektor jasa-jasa unggul di Kota Samarinda.Yang menjadi kawasan andalan sebagai pusat pertumbuhan pada tingkat Kabupaten/Kota di Kalimantan Timur adalah Kota Balikpapan dan Kota Tarakan.
\end{abstract}

Kata Kunci: Tipologi klasssen, location quotient (LQ), kawasan andalan. 


\section{PENDAHULUAN}

Kawasan andalan dalam Rencana Tata Ruang Wilayah Nasional adalah suatu kawasan yang dikembangkan untuk mengurangi kesenjangan antar daerah melalui pengembangan kegiatan ekonomi yang diandalkan sebagai motor penggerak pengembangan wilayah. Kawasan andalan diharapkan mampu menjadi pusat dan pendorong pertumbuhan ekonomi bagi kawasan di sekitarnya. Kawasan andalan juga diharapkan mampu bersaing di dalam dan luar negeri. Kemampuan bersaing ini lahir melalui pengembangan produk unggulan yang kompetitif di pasar domestik maupun global, yang didukung sumber daya manusia (SDM) unggul, riset dan teknologi, informasi, serta keunggulan pemasaran. Sementara itu dalam pelaksanaan di daerah, konsep pengembangan kawasan andalan tidak secara efektif dikembangkan, sehingga tidak pernah dapat diukur keberhasilannya.

Program pengembangan wilayah telah banyak dikembangkan, namun kurang optimal, karena menekankan pada sisi pengelolaan project oriented, kurang terfokus pada kesinambungan program jangka panjang, serta terhalang masalah-masalah lainnya.

$$
\text { Pada wilayah Provinsi }
$$

Kalimantan Timur kinerja ekonomi nasional menunjukkan akselerasi pertumbuhan ekonomi yang masih terus berlanjut didorong oleh peningkatan produktivitas komoditas unggulan khususnya batubara dan beberapa hasil pertanian. Faktor lain yang turut mendorong kinerja ekonomi tersebut yaitu kuatnya konsumsi dalam negeri didukung oleh berbagai faktor diantaranya daya beli yang membaik, dukungan pembiayaan yang meningkat, serta kepercayaan konsumen dan dunia usaha yang membaik. Sementara itu, perbaikan investasi terus berlanjut sejalan dengan implementasi berbagai kebijakan yang mendukung kegiatan investasi dan perbaikan persepsi pasar terhadap perekonomian. Situasi inilah yang turut mendorong kinerja ekonomi nasional termasuk Kalimantan Timur mengalami pertumbuhan positif.

Bila dilihat dari Produk Domestik Regional Bruto (PDRB) atas dasar harga konstan 2000 yang memberikan sumbangan terbesar adalah sektor pertambangan dan 
penggalian sebesar Rp 11,7 triliun.

Untuk selanjutnya ada sektor industri pengolahan sebesar $\mathrm{Rp} \mathrm{7,5} \mathrm{triliun,}$ sektor perdagangan, hotel dan restoran sebesar Rp 2,5 triliun, sektor pertanian sebesar $\mathrm{Rp} \quad 1,7$ triliun, sektor pengangkutan dan komunikasi sebesar Rp 1,6 triliun, sektor konstruksi atau bangunan sebesar $\mathrm{Rp}$ 1,2 triliun, sektor keuangan dan persewaan sebesar Rp 0,9 triliun, sektor jasa-jasa sebesar Rp 0,5 triliun, dan sektor listrik dan air bersih sebesar Rp 90,1 milyar.

Berdasarkan data pada tabel 1, pertumbuhan ekonomi yang terjadi di Kalimantan Timur tersebut berasal dari potensi-potensi yang ada di berbagai Kabupaten/Kota.

Kalimantan Timur memiliki tiga belas Kabupaten/Kota yaitu: Kabupaten Paser, Kabupaten Kutai Barat, Kabupaten Kutai Timur, Kabupaten Kutai Kartanegara, Kabupaten Berau, Kabupaten Malinau, Kabupaten Bulungan, Kabupaten Nunukan, Kabupaten Penajam Paser Utara, Kota Balikpapan, Kota Samarinda, Kota Tarakan dan Kota Bontang. Dari tiga belas Kabupaten/Kota ini peneliti ingin mengetahui potensi-potensi yang ada pada setiap Kabupaten/Kota untuk dikembangkan menjadi kawasan andalan sebagai pusat pertumbuhan.

\section{Tabel 1. PDRB Kalimantan Timur Menurut Lapangan Usaha Triwulan IV} Tahun 2010 (Juta Rp)

\begin{tabular}{llrr}
\hline No & \multicolumn{1}{c}{ Lapangan Usaha } & \multicolumn{1}{c}{$\begin{array}{c}\text { Harga } \\
\text { Berlaku }\end{array}$} & $\begin{array}{c}\text { Harga } \\
\text { Konstan } \\
\text { Th 2000) }\end{array}$ \\
\hline 1. & Pertanian & 4.652 .083 & 1.723 .227 \\
2. & Pertambangan \& Penggalian & 39.991 .585 & 11.677 .172 \\
3. & Industri Pengolahan & 19.956 .953 & 7.546 .330 \\
4. & Listrik \& Air Bersih & 223.380 & 90.520 \\
5. & Konstruksi & 2.393 .036 & 1.149 .935 \\
6. & Perdagangan, Hotel \& Restoran & 7.023 .971 & 2.539 .080 \\
7. & Pengangkutan \& Komunikasi & 3.174 .964 & 1.649 .721 \\
8. & Keuangan, Persewaan \& Jasa Perusahaan & 2.002 .268 & 926.647 \\
9. Jasa-jasa & 3.560 .998 & 594.731 \\
\hline & PDRB & 82.979 .239 & 27.897 .362 \\
\hline
\end{tabular}

Sumber: BPS Provinsi Kaltim 
Pertumbuhan kawasan andalan diharapkan dapat memberikan imbas positif bagi pertumbuhan ekonomi daerah sekitar (hiterland), melalui pemberdayaan sektor/subsektor unggulan sebagai penggerak perekonomian daerah dan keterkaitan ekonomi antardaerah. Penekanan pada pertumbuhan ekonomi sebagai arah kebijakan penetapan kawasan andalan adalah mengingat "pertumbuhan ekonomi merupakan salah satu variabel ekonomi yang merupakan indikator kunci dalam pembangunan" (Kuncoro, 2000:18).

\section{METODE PENELITIAN}

Penelitian ini melakukan pengamatan pada pola pertumbuhan ekonomi, sektor unggulan serta kawasan andalan pada seluruh Kabupaten/Kota di Kalimantan Timur. Pada penelitian ini data yang digunakan adalah data Produk Domestik Regional Bruto (PDRB) mulai tahun 2005-2009. Adapun teknik analisis data menggunakan perhitungan pertumbuhan ekonomi, Tipologi Klassen dan Location Quotient (LQ).

\section{PEMBAHASAN}

Analisis Tipologi Klassen digunakan untuk menetapkan pola dan struktur pertumbuhan ekonomi dari tiga belas Kabupaten/Kota di Kalimantan Timur berdasarkan dua indikator utama, yaitu PDRB Sembilan sektor dan pendapatan perkapita tahun 2005-2009. Pola dan struktur pertumbuhan ekonomi Kabupaten/Kota di Kalimantan Timur berdasarkan Tipologi Klassen dibagi menjadi empat klasifikasi, yaitu: daerah cepat maju dan cepat tumbuh, daerah maju tapi tertekan, daerah berkembang cepat dan daerah relatif tertinggal. Berdasarkan perhitungan Tipologi Klassen cara untuk mengetahuinya membandingkan PDRB perkapita dengan pertumbuhan ekonomi serta menentukan rata-rata pertumbuhan ekonomi dan rata-rata PDRB per kapita. 
Tabel 2. Matrik Klasifikasi Pertumbuhan Ekonomi Kabupaten/Kota di Kalimantan Timur

\begin{tabular}{|c|c|c|}
\hline PDRB perkapita (y) & yi < y & $y i>y$ \\
\hline $\mathrm{ri}>\mathrm{r}$ & $\begin{array}{l}\text { Daerah berkembang } \\
\text { cepat: } \\
\text { Kab. Paser } \\
\text { Kab. Kubar } \\
\text { Kab. Berau } \\
\text { Kab. Malinau } \\
\text { Kab. Bulungan } \\
\text { Kab. Nunukan } \\
\text { Kab. PPU } \\
\text { Kota Samarinda } \\
\text { Kota Tarakan } \\
\end{array}$ & $\begin{array}{l}\text { Daerah cepat maju dan cepat } \\
\text { tumbuh: } \\
\text { Kab. Kutim } \\
\text { Kota Balikpapan }\end{array}$ \\
\hline $\mathrm{ri}<\mathrm{r}$ & $\begin{array}{l}\text { Daerah relatif } \\
\text { tertinggal: } \\
-\end{array}$ & $\begin{array}{l}\text { Daerah maju tapi tertekan: } \\
\text { Kab. Kukar } \\
\text { Kota Bontang }\end{array}$ \\
\hline
\end{tabular}

Sumber : BPS Prov. Kaltim (Data Diolah)

Kabupaten/Kota di Kalimantan Barat, Kabupaten Berau, Kabupaten

Timur terdapat dua daerah cepat maju Malinau, Kabupaten Bulungan,

cepat tumbuh yaitu Kabupaten Kutai Kabupaten Nunukan, Kabupaten

Timur dan Kota Balikpapan yang Penajam Paser Utara, Kota

memiliki PDRB perkapita dan Samarinda, dan Kota Tarakan.

pertumbuhan ekonomi yang tinggi. Sementara untuk daerah relatif

Pada daerah yang memiliki PDRB tertinggal tidak ada Kabupaten/Kota

perkapita tinggi dan pertumbuhan yang termasuk dalam klasifikasi

ekonomi yang rendah merupakan tersebut. Hal ini menunjukkan bahwa

daerah maju tapi tertekan yaitu tidak ada Kabupaten/Kota di

Kabupaten Kutai Kertanegara dan Kalimantan Timur yang memiliki

Kota Bontang. Klasifikasi yang PDRB perkapita dan pertumbuhan

ketiga, daerah berkembang cepat yang ekonomi yang rendah.

memiliki PDRB perkapita rendah dan Pembahasan berikutnya yaitu

pertumbuhan ekonomi yang tinggi penentuan Sektor Unggulan

terdapat sembilan daerah yaitu Kabupaten/Kota di Kalimantan

Kabupaten Paser, Kabupaten Kutai Timur, untuk menentukan kategori 
sektor unggulan atau sektor bukan unggulan pada Kabupaten/Kota di Kalimantan Timur digunakan alat analisis Location Quotient (LQ). Sektor unggulan merupakan sektor yang mempunyai peranan yang kuat di suatu daerah bila dibandingkan dengan sektor yang sama pada daerah lain dalam suatu Provinsi.

Berdasarkan perhitungan LQ dapat di ketahui mana sektor unggulan dan sektor bukan unggulan yang dimiliki oleh setiap Kabupaten/Kota di Kalimantan Timur. Kabupaten Paser memiliki tiga sektor unggulan yaitu sektor pertanian (LQ=2.42), sektor pertambangan dan penggalian $(\mathrm{LQ}=1.82), \quad$ dan $\quad$ sektor jasa-jasa ( $\mathrm{LQ}=1.38)$. Dilihat dari rata-rata tiga sektor unggulan tersebut Kabupaten Paser sangat bergantung pada sektor pertanian karena merupakan mata pencaharian dari sebagian besar masyarakat dan lahan pertanian yang paling potensial adalah tanaman padi yang setiap tahunnya mengalami peningkatan terus menerus.

Kabupaten Kutai Barat memiliki empat sektor unggulan yaitu sektor pertanian $(\mathrm{LQ}=2.84)$, sektor pertambangan dan penggalian
$(\mathrm{LQ}=1.27), \quad$ sektor $\quad$ konstruksi $(\mathrm{LQ}=4.09)$, dan sektor jasa-jasa $(\mathrm{LQ}=1.94)$. Dilihat dari rata-rata empat sektor unggulan tersebut Kabupaten Kutai Barat sangat bergantung pada sektor konstruksi yang memiliki tujuan untuk mengatasi keterisolasian wilayah, baik fisik maupun komunikasi diarahkan pada peningkatan aksesbilitas masyarakat terhadap media komunikasi dan informasi dan penyediaan jaringan listrik untuk kampung yang belum tersentuh oleh listrik. Dari tujuan tersebut maka sangat mempengaruhi perekonomian pada Kabupaten Kutai Barat.

Kabupaten Kutai Kartanegara memiliki tiga sektor unggulan yaitu sektor pertanian $(\mathrm{LQ}=1.13)$, sektor pertambangan dan penggalian $(\mathrm{LQ}=2.03)$, dan sektor konstruksi $(\mathrm{LQ}=1.21)$. Dilihat dari rata-rata tiga sektor unggulan tersebut sektor pertambangan dan penggalian memegang peranan penting dalam perekonomian Kabupaten Kutai Kartanegara terutama pertambangan minyak dan gas bumi, juga termasuk batu bara, emas, perak dan lain-lain karena memberi sumbangan nilai 
tambah terbesar dan mempengaruhi nilai PDRB.

\section{Pada Kabupaten Kutai Timur} hanya terdapat satu sektor unggulan yang menonjol yaitu sektor pertambangan dan penggalian $(\mathrm{LQ}=2.24)$ Berdasarkan data perekonomian Kabupaten Kutai Timur sangat bergantung pada sektor pertambangan dan penggalian yang merupakan penyumbang terbesar dalam pendapatan daerah di banding dengan sektor-sektor yang lainnya. Salah satu penyebabnya Kutai Timur merupakan wilayah pertambangan karena di wilayah Sangkima terdapat kandungan minyak dan gas bumi, di Sangatta Utara terdapat pertambangan batu bara, di wilayah Muara Ancalong, Muara Wahau dan Telen terdapat pertambangan dan penggalian Emas, dan masih banyak lagi wilayah lain yang kandungan batu bara dan minyak dan gas bumi melimpah.

Kabupaten Berau memiliki lima sektor unggulan yaitu sektor pertanian ( $\mathrm{LQ}=3.31$ ), sektor pertambangan dan penggalian $(\mathrm{LQ}=1.02), \quad$ sektor perdagangan, hotel dan restoran (LQ=1.61), sektor pengangkutan dan komunikasi ( $\mathrm{LQ}=1.39$ ) serta sektor jasa-jasa $(\mathrm{LQ}=1.60)$. Dilihat dari ratarata lima sektor unggulan tersebut perekonomian pada Kabupaten Berau sangat bergantung pada sektor pertanian. Hal ini disebabkan Kabupaten Berau sebagai daerah yang kaya akan sumber daya alam dan potensi lahan pertanian cukup besar, menempatkan sektor pertanian sebagai salah satu sektor yang diprioritaskan dalam pembangunan.

Pembangunan Pertanian Tanaman Pangan dan Hortikultura serta Peternakan sampai saat ini masih sangat penting, karena pangan merupakan salah satu kebutuhan pokok manusia, khususnya beras sebagai makanan pokok masyarakat Berau. Peran sektor pertanian tersebut semakin penting karena merupakan sektor yang berbasis sumber daya alam tanpa atau relatif tidak tergantung pada komponen impor sehingga mampu bertahan menghadapi krisis ekonomi yang berkepanjangan.

Kabupaten Malinau memiliki lima sektor unggulan yaitu sektor pertanian $(\mathrm{LQ}=6.23)$, sektor listrik, gas dan air bersih (LQ=1.21), sektor konstruksi $\quad(\mathrm{LQ}=6.55), \quad$ sektor perdagangan, hotel dan restoran 
$(\mathrm{LQ}=2.52)$ serta sektor jasa-jasa kontribusi terbesar dari sektor (LQ=2.42). Dilihat dari rata-rata lima sektor unggulan tersebut perekonomian pada Kabupaten Malinau bergantung pada dua sektor yaitu sektor pertanian dan sektor bangunan. Hal ini dikarenakan dua sektor tersebut saling terkait satu sama lain, Pembangunan di bidang pertanian memegang peranan penting dalam pembangunan ekonomi, terutama untuk meningkatkan taraf hidup petani sebagai kelompok besar masyarakat, di samping untuk mendukung pertumbuhan industri. Pertanian yang meliputi pertanian tanaman pangan, perkebunan, kehutanan, perikanan dan peternakan selalu diupayakan untuk menunjang pertumbuhan dan stabilitas ekonomi.

Kabupaten Bulungan memiliki lima sektor unggulan yaitu sektor pertanian ( $\mathrm{LQ}=4.24)$, sektor listrik, gas dan air bersih $(\mathrm{LQ}=2.79)$, sektor perdagangan, hotel dan restoran (LQ=1.75), sektor pengangkutan dan komunikasi ( $\mathrm{LQ}=1.48)$ serta sektor jasa-jasa (LQ=3.20). Dilihat dari ratarata lima sektor tersebut perekonomian pada Kabupaten Bulungan bergantung pada sektor pertanian. Yang memberikan pertanian adalah bagian kehutanan walaupun nilai kontribusinya cenderung menurun. Selain itu yang berprospek cerah dengan trend meningkat adalah peternakan dan perikanan.

Kabupaten Nunukan memiliki enam sektor unggulan yaitu sektor pertanian ( $\mathrm{LQ}=4.34), \quad$ sektor pertambangan dan penggalian $(\mathrm{LQ}=1.06)$, sektor listrik, gas dan air bersih ( $\mathrm{LQ}=2.13)$, sektor konstruksi ( $L Q=2.36$ ), sektor perdagangan, hotel dan restoran $(\mathrm{LQ}=1.67)$ serta sektor jasa-jasa (LQ=2.58). Dilihat dari enam sektor unggulan tersebut perekonomian pada Kabupaten Nunukan sangat bergantung pada sektor pertanian. Tiga komoditas unggulan sektor pertanian yang dikembangkan adalah Padi, Kedelai dan Jagung. Walaupun komoditas padi yang paling dominan dalam menunjang pertumbuhan dan stabilitas ekonomi. Selain itu, beberapa komoditas yang masih potensial untuk dikembangkan adalah Mangga, Durian dan Pisang.

Kabupaten Penajam Paser Utara memiliki empat sektor unggulan yaitu sektor pertanian $(\mathrm{LQ}=2.08)$, sektor 
pertambangan dan penggalian luar daerah. Semakin banyak investor (LQ=1.10), sektor perdagangan, hotel dan restoran $(\mathrm{LQ}=1.64)$, serta sektor jasa-jasa $(\mathrm{LQ}=1.82)$. Dilihat dari ratarata empat sektor unggulan tersebut perekonomian pada Kabupaten Penajam Paser Utara bergantung pada sektor pertanian. Ada lima komoditi unggulan yaitu kopi, kelapa dalam, kelapa sawit, kakao, dan gula merah. Dari lima komoditi tersebut memiliki kontribusi terbesar dalam peningkatan PDRB dan penyerapan tenaga kerja.

Kota Balikpapan memiliki tujuh sektor unggulan yaitu sektor industri pengolahan $(\mathrm{LQ}=1.19)$, sektor listrik, gas dan air bersih $(\mathrm{LQ}=2.80)$, sektor konstruksi $(\mathrm{LQ}=3.79), \quad$ sektor perdagangan, hotel dan restoran ( $\mathrm{LQ}=3.48$ ), sektor pengangkutan dan komunikasi $\quad(\mathrm{LQ}=2.15), \quad$ sektor keuangan, persewaan dan jasa perusahaan ( $\mathrm{LQ}=1.09)$ serta sektor jasa-jasa $(L Q=1.52)$. Dilihat dari ratarata tujuh sektor unggulan tersebut pendapatan daerah Kota Balikpapan banyak di sumbangkan dari sektor konstruksi dan sektor perdagangan, hotel dan restoran. Hal ini di karenakan dua sektor tersebut yang paling diminati atau menjadi daya tarik bail bagi investor lokal ataupun yang datang maka semakin banyak pula menanamkan modalnya sehingga dapat meningkatkan perekonomian.

Kota Samarinda memiliki enam sektor unggulan yaitu sektor listrik, gas dan air bersih (LQ=4.16), sektor konstruksi $\quad(\mathrm{LQ}=1.75), \quad$ sektor perdagangan, hotel dan restoran (LQ=3.36), sektor pengangkutan dan komunikasi $\quad(\mathrm{LQ}=2.28), \quad$ sektor keuangan, persewaan dan jasa perusahaan $(\mathrm{LQ}=4.39)$ serta sektor jasa-jasa ( $L Q=6.43)$. Dilihat dari ratarata enam sektor unggulan tersebut pendapatan daerah pada kota Samarinda banyak di sumbangkan dari sektor jasa-jasa. Hal ini dikarenakan Kota Samarinda merupakan pusat distribusi penduduk Kalimantan Timur. Seperti contohnya pelabuhan yang merupakan tempat masuknya barang atau peredaran jasa dari berbagai daerah yang kemudian di distribusikan ke berbagai sudut Kota Samarinda bahkan seluruh Kalimantan Timur.

Kota Tarakan memiliki tujuh sektor unggulan yaitu sektor pertanian (LQ=1.53), sektor listrik, gas dan air bersih ( $\mathrm{LQ}=7.32)$, sektor konstruksi $(\mathrm{LQ}=1.22)$, sektor perdagangan, hotel 
dan restoran ( $\mathrm{LQ}=5.22)$, sektor lainnya. Hal ini di karenakan Kota pengangkutan dan komunikasi Bontang merupakan tempat (LQ=2.19), sektor keuangan, pengolahan industri yang terbesar di persewaan dan jasa perusahaan Kalimantan Timur, Gas Alam Cair $(\mathrm{LQ}=3.66)$ serta sektor jasa-jasa (LNG) merupakan komoditi utama (LQ=3.05). Dilihat dari rata-rata tujuh yang menopang perekonomian Kota sektor unggulan tersebut pendapatan Bontang. Kota ini dianugrahi daerah pada Kota Tarakan banyak di kekayaan alam, terutama gas alam sumbangkan oleh sektor listrik, gas, dan air bersih. Pada salah satunya yaitu listrik, pemerintah kota tarakan sangat menaruh perhatian yang sungguh-sungguh terhadap ketersediaan tenaga listrik tersebut. Agar pelayanan dapat lebih baik, maka setelah melalui proses sosialisasi dan didukung oleh berbagai elemen masyarakat, disepakati untuk memberlakukan Tarif Dasar Listrik Lokal.

Kota Bontang memiliki dua sektor unggulan yaitu sektor industri pengolahan $(\mathrm{LQ}=2.84)$ dan sektor konstruksi $(\mathrm{LQ}=1.05)$. Berdasarkan tabel di atas sektor industri pengolahan tersebut memberikan kontribusi paling besar dalam pendapatan daerah di Kota Bontang di banding dengan sektor-sektor yang yang sangat besar.

Hasil analisis Tipologi Klassen menunjukkan bahwa Kabupaten Kutai Timur dan Kota Balikpapan merupakan daerah cepat maju dan cepat tumbuh. Sedangkan untuk analisis Location Quotient ( $L Q)$ Kota Balikpapan dan Kota Tarakan memiliki sektor unggulan sebanyak tujuh sektor unggulan.

Berdasarkan analisis gabungan antara analisis tipologi klassen dan analisis Location Quotient (LQ) maka dapat diketahui kawasan andalan yang menjadi pusat pertumbuhan pada tingkat Kabupaten/Kota di Kalimantan Timur adalah Kota Balikpapan dan Kota Tarakan. 


\section{Gambar 1. Peta Kawasan Andalan Kabupaten/Kota di Kalimantan Timur}

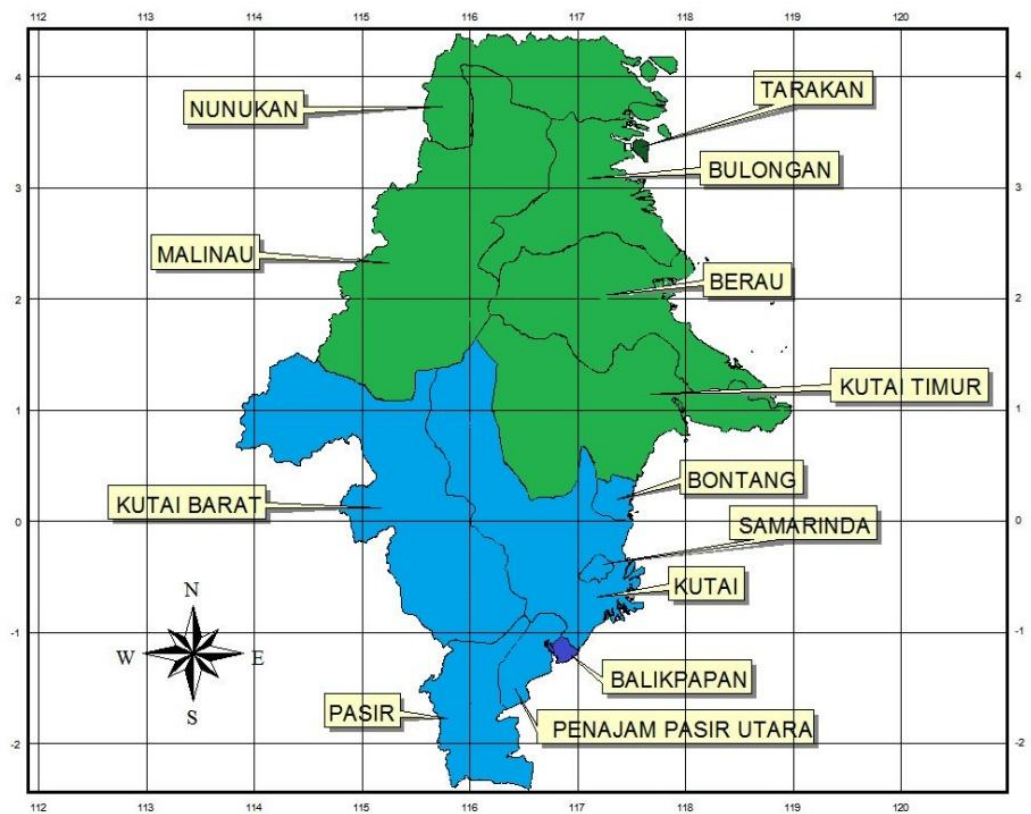

Sumber: BPS Prov Kaltim (Data Diolah)

Ket: Warna biru: kawasan andalan Balikpapan; Warna hijau: kawasan andalan Tarakan

Hal ini dikarenakan Kota tahun 2008 tentang Rencana Tata Balikpapan sebagai pusat Ruang Wilayah Nasional yang telah perekonomian yang mempengaruhi di ditetapkan sebagai Pusat Kegiatan wilayah sekitar Kabupaten Paser, Nasional dan Kawasan Andalan Kabupaten Kutai Barat, Kabupaten Nasional.

Kutai Kartanegara, Kabupaten PENUTUP

Penajam Paser Utara, Kota Pola pertumbuhan ekonomi Samarinda, dan Kota Bontang. pada tingkat Kabupaten/Kota di Sedangkan Kota Tarakan sebagai Kalimantan Timur berdasarkan pusat perekonomian yang analisis Tipologi Klassen. Daerah mempengaruhi di wilayah sekitar cepat maju dan cepat tumbuh dimiliki Kabupaten Kutai Timur, Kabupaten oleh Kabupaten Kutai Timur dan Berau, Kabupaten Malinau, Kota Balikpapan. Daerah maju tapi Kabupaten Bulungan, dan Kabupaten tertekan terdapat Kabupaten Kutai Nunukan.

Kartanegara dan Kota Bontang.

Penetapan Kawasan Andalan Untuk daerah berkembang cepat tersebut juga sesuai dengan PP 26 terdapat Kabupaten Paser, Kabupaten 
Kutai Barat, Kabupaten Berau, adalah Kota Balikpapan dan Kota Kabupaten Malinau, Kabupaten Tarakan.

Nunukan, Kabupaten Penajam Paser

Utara, Kota Samarinda, dan Kota

Tarakan. Sedangkan untuk daerah relatif tertinggal tidak terdapat pada Kabupaten/Kota di Kalimantan Timur.

Sektor yang menjadi unggulan pada tingkat Kabupaten/Kota di Kalimantan Timur berdasarkan perhitungan Location Quotient (LQ). Sektor pertanian unggul di Kabupaten Malinau, sektor pertambangan \& penggalian unggul di Kabupaten Kutai Timur, sektor industri pengolahan unggul di Kota Bontang, sektor listrik, gas \& air bersih unggul di Kota Tarakan, sektor bangunan unggul di Kota Balikpapan, sektor perdagangan, hotel \& restoran unggul di Kota Tarakan, sektor pengangkutan \& komunikasi unggul di Kota Samarinda, sektor keuangan, persewaan $\&$ jasa perusahaan unggul di Kota Samarinda, dan sektor jasajasa unggul di Kota Samarinda. Adapun daerah yang menjadi kawasan andalan sebagai pusat pertumbuhan pada tingkat Kabupaten/Kota di Kalimantan Timur

\section{DAFTAR PUSTAKA}

Armstrong, Harvey and Jim Taylor, (1993), Regional Economics and Policy, Second Edition, Harvester Wheatsheaf.

Aswandi, Hairul \& Kuncoro, Mudrajad. 2002. Evaluasi Penetapan Kawasan Andalan: Studi empiris di Kalimantan Selatan 1993-1999. Jurnal Ekonomi dan Bisnis Indonesia, Vol 17 No.1, Hal 27-45.

Kabupaten/Kota

Kalimantan Timur Menurut Lapangan Usaha, Tahun 2005-2009. BPS Provinsi Kalimantan Timur

Berita Resmi Statistik Provinsi Kalimantan Timur. 2011. Kalimantan Timur Dalam Angka 2010. (Online) (http:/kaltim.bps.go.id, diakses 3 Maret 2011)

Berita Resmi Statistik Provinsi Kalimantan Timur. 2011. Perekonomian Kalimantan Timur Triwulan IV Tahun 2010 tumbuh 0,75 persen atau 2,36 persen. (Online) (http://kaltim.bps.go.id, diakses 17 Februari 2011)

Boediono. 1999. Teori Pertumbuhan Ekonomi. BPFE. Yogyakarta. 
Direktorat Pengembangan Kawasan

Khusus dan Tertinggal Deputi

Bidang Otonomi Daerah dan

Pengembangan Regional

Bappenas. 2002.

Pengembangan Ekonomi

Daerah Berbasis Kawasan

Andalan: Membangun Model

Pengelolaan dan

Pengembangan Keterkaitan

Program. (Online)

(http://google.com, diakses 26

Desember 2010)

Kuncoro, Mudrajad, 2000. Ekonomi

Pembangunan

(Teori,

Masalah dan Kebijakan),

Edisi Pertama, UPP AMP

YKPN, Yogyakarta.

Rahardjo Adisasmita. 2005.

Dasar-dasar Ekonomi

Wilayah. Graha Ilmu.

Yogyakarta.

Royat, Sujana. 1996. Pembangunan Ekonomi Regional dan Upaya Menunjang Pertumbuhan
KAPET Dalam Kaitannya

Dengan Kemitraan Antara

Pemerintah, Swasta dan

Masyarakat. Manajemen

Usahawan Indonesia, No.12, Tahun XXV, 14-17.

Samuelson, Paul A and Nordhaus, William D. 1996.

Makroekonomi (terjemahan oleh: Haris Munandar, dkk). Erlangga. Jakarta.

Sjafrizal. 1997. Pertumbuhan Ekonomi dan Ketimpangan Regional wilayah Indonesia Bagian Barat. Prisma. Jakarta

Tarigan, Robinson. 2004. Ekonomi Regional: Teori dan Aplikasi. Bumi Aksara. Jakarta.

Todaro, M.P, 2000, Economic Development, Seventh Editions, New York, Addition Wesley Longman, Inc. 